\title{
SPINT1 wt Allele
}

National Cancer Institute

\section{Source}

National Cancer Institute. SPINT1 wt Allele. NCI Thesaurus. Code C107611.

Human SPINT 1 wild-type allele is located in the vicinity of 15q15.1 and is approximately $14 \mathrm{~kb}$ in length. This allele, which encodes Kunitz-type protease inhibitor 1 protein, is involved in both the inhibition of proteolysis and the modulation of growth factor signaling. 